\title{
Relationship between land use and soil erosion in a typical area in the tableland and gully region of the Loess Plateau, China
}

\author{
Jianxiang Zhang ${ }^{1}$, Naiang Wang ${ }^{1}$, Duoyong Zhang ${ }^{2}$, and Xianbao $\mathrm{Su}^{1}$ \\ ${ }^{1}$ Lanzhou University \\ ${ }^{2}$ North Minzu University
}

May 5, 2020

\begin{abstract}
Soil erosion is an important environmental problem that threatens human ecological security and socioeconomic development. Unreasonable land use is one of the main causes of soil erosion. By collecting the topography, climate, soil, vegetation and satellite image data of Dongzhiyuan (DZY) in the tableland and gully region (TGR) of the Loess Plateau (LP), the Revised Universal Soil Loss Equation (RUSLE) and the Chinese Soil Loss Equation (CSLE) models were used to simulate the soil erosion intensity in different periods (1987, 1997, 2007 and 2017). We found that under high rainfall erosivity factor (R), the soil erosion usually be overestimated in the RUSLE model. However, the result has been changed when we use the annual average R.Besides, the model of CSLE based on the RUSLE takes engineering measure factor (E) into account, making the results more reliable. Also, land use change will affect soil erosion. The conversion of urban to farmland and grassland will increase soil erosion, and vice versa. The mutual transfer between farmland and grassland, forest and grassland will cause soil erosion to change in different directions, and the greater of land use change, the more serious soil erosion will be. Nevertheless, we shouldn't increase the urban land by mountain excavation and gully filling blindly. Otherwise, geological disasters such as landslides and surface subsidence may occur in the near future. This work may enhance our understanding of soil erosion mechanisms in DZY, and provide references for land use planning and soil and water conservation in China's Loess Plateau.
\end{abstract}

\section{Hosted file}

Main Document 3.13.doc available at https://authorea.com/users/301345/articles/434350relationship-between-land-use-and-soil-erosion-in-a-typical-area-in-the-tableland-andgully-region-of-the-loess-plateau-china

\section{Hosted file}

Figure 1.tif available at https://authorea.com/users/301345/articles/434350-relationshipbetween-land-use-and-soil-erosion-in-a-typical-area-in-the-tableland-and-gully-regionof-the-loess-plateau-china

\section{Hosted file}

Figure 2.tif available at https://authorea.com/users/301345/articles/434350-relationshipbetween-land-use-and-soil-erosion-in-a-typical-area-in-the-tableland-and-gully-regionof-the-loess-plateau-china

\section{Hosted file}

Figure 3.tif available at https://authorea.com/users/301345/articles/434350-relationshipbetween-land-use-and-soil-erosion-in-a-typical-area-in-the-tableland-and-gully-regionof-the-loess-plateau-china 


\section{Hosted file}

Figure 4.tif available at https://authorea.com/users/301345/articles/434350-relationshipbetween-land-use-and-soil-erosion-in-a-typical-area-in-the-tableland-and-gully-regionof-the-loess-plateau-china

\section{Hosted file}

Figure 5.tif available at https://authorea.com/users/301345/articles/434350-relationshipbetween-land-use-and-soil-erosion-in-a-typical-area-in-the-tableland-and-gully-regionof-the-loess-plateau-china

\section{Hosted file}

Figure 6.tif available at https://authorea.com/users/301345/articles/434350-relationshipbetween-land-use-and-soil-erosion-in-a-typical-area-in-the-tableland-and-gully-regionof-the-loess-plateau-china

\section{Hosted file}

Figure 7.tif available at https://authorea.com/users/301345/articles/434350-relationshipbetween-land-use-and-soil-erosion-in-a-typical-area-in-the-tableland-and-gully-regionof-the-loess-plateau-china

\section{Hosted file}

Figure 8.tif available at https://authorea.com/users/301345/articles/434350-relationshipbetween-land-use-and-soil-erosion-in-a-typical-area-in-the-tableland-and-gully-regionof-the-loess-plateau-china

\section{Hosted file}

Figure 9.tif available at https://authorea.com/users/301345/articles/434350-relationshipbetween-land-use-and-soil-erosion-in-a-typical-area-in-the-tableland-and-gully-regionof-the-loess-plateau-china

\section{Hosted file}

Figure 10.tif available at https://authorea.com/users/301345/articles/434350-relationshipbetween-land-use-and-soil-erosion-in-a-typical-area-in-the-tableland-and-gully-regionof-the-loess-plateau-china

\section{Hosted file}

Table1-5.doc available at https://authorea.com/users/301345/articles/434350-relationshipbetween-land-use-and-soil-erosion-in-a-typical-area-in-the-tableland-and-gully-regionof-the-loess-plateau-china 